Recibido: 28 junio 2012

Aprobado: 5 septiembre 2012
The Baroque city center, photo by M. D'Ottavio

** Architect, Ph.D. in Architecture and Building Design. Since 2009 she is Adjunct Professor in Architecture and Urban Design at Politecnico of Torino (Italy). Since 2005 she is a member of the Design Team at Urban Center Metropolitano Torino (Italy), an association that works both with public and private players on urban and architectural transformation. francesca.camorali@polito.it francesca.camorali@urbancenter.to.it

\section{THE INERTIA OF THE SIGNS. THE ARCHITECTURAL PROJECT AS A TOOL OF RESEARCH IN THE EXPERIENCE OF URBAN CENTER METROPOLITANO TORINO*}

Francesca Camorali***

Politecnico of Torino (Italia)

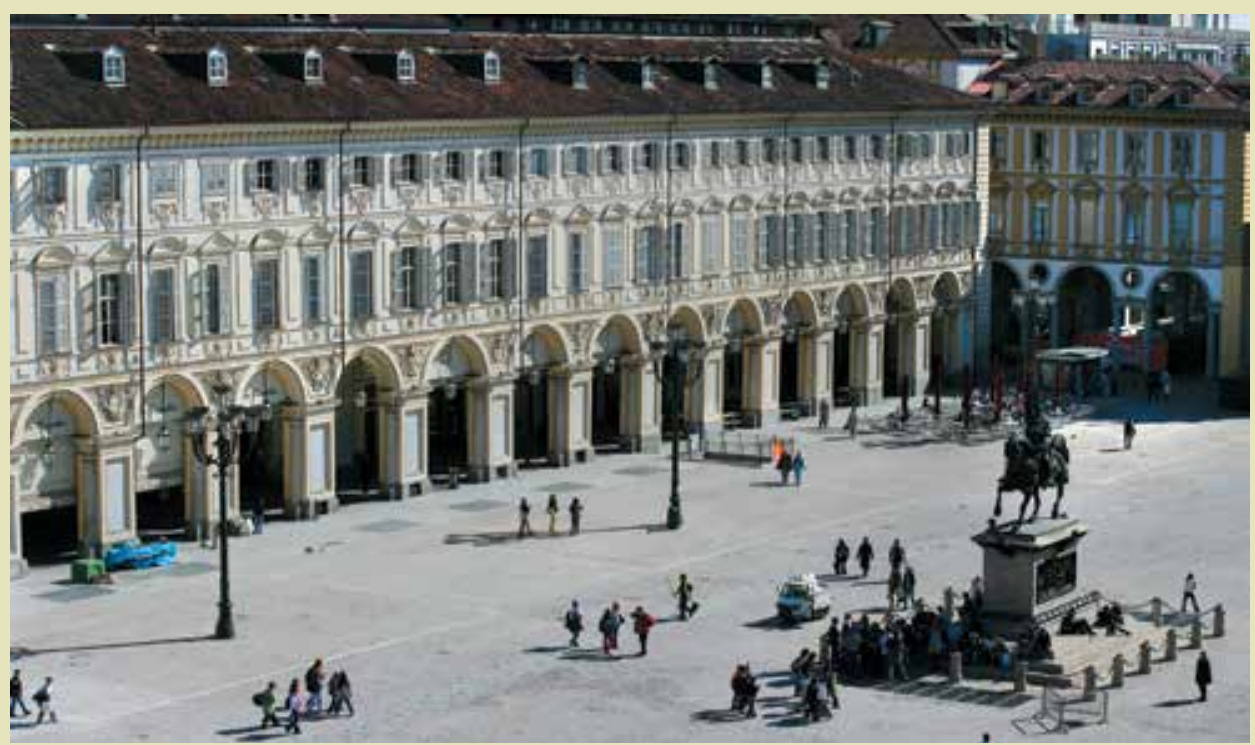

\section{ABSTRACT}

Located in the North-West of Italy, Torino ( 900.000 inhabitants) is the city of the automotive company FIAT. The city has recently experienced a deep process of urban transformation, which began with the XXWinter Olympic Games in 2006 and, before that, with the disposal of unused factories' several millions of square meters. For this reason, Torino is today an interesting case study. The paper particularly deals with a critical reading of the experience of the Urban Center Metropolitano Torino (UCM), an association that was born in 2005 for accompanying the urban and regional planning and the renewal processes. UCM is an interesting experience from both a methodological and an operational point of view: doing its work with the various actors, the public and the private ones, UCM explores different uses of the architectural project, practicing its main skill that is to "draw a shape". It is for this reason that in the UCM's activities the project can take many different roles: it can be a tool of knowledge, of foreshadowing, of discussion.

\section{KEYWORDS}

Architectural project, Urban transformation, City's shape 


\section{LA INERCIA DE LOS SIGNOS. EL PROYECTO DE ARQUITECTURA COMO INSTRUMENTO DE INVESTIGACIÓN EN LA EXPERIENCIA DEL URBAN CENTER METROPOLITANO TORINO}

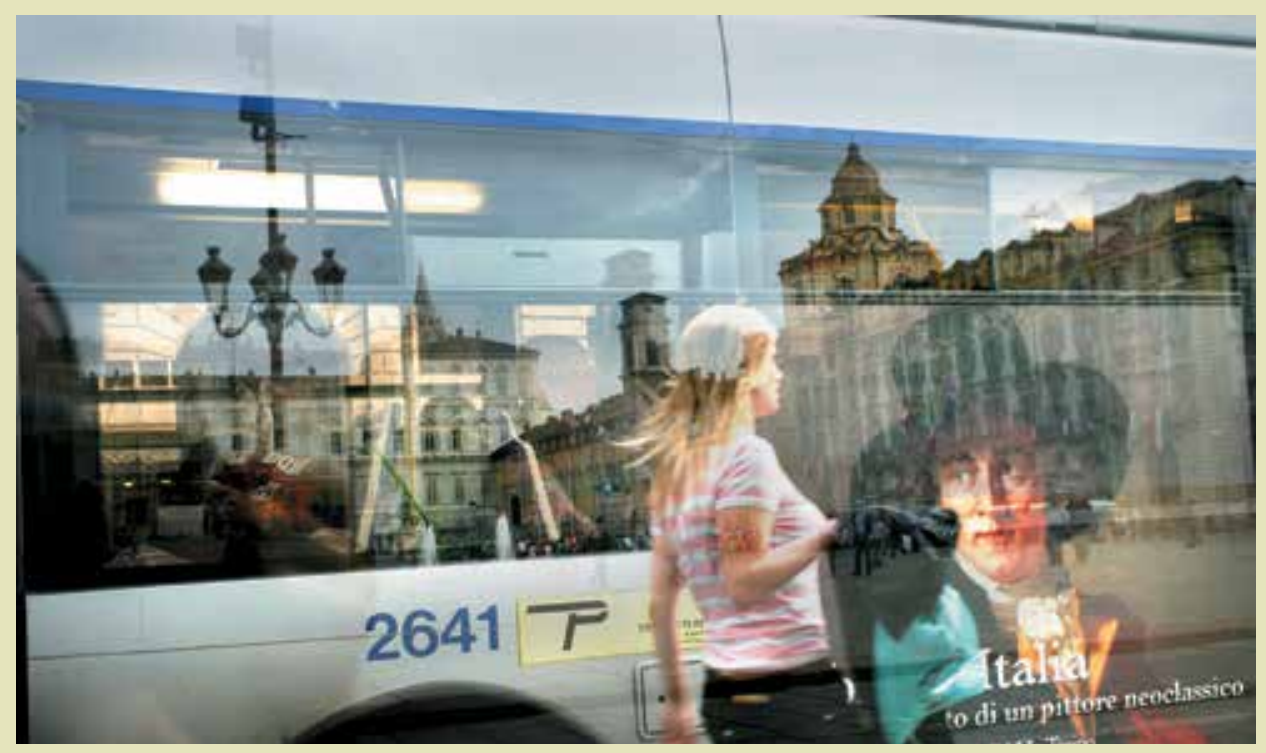

\section{RESUMEN}

Situada en la parte noroeste de Italia, Turín (900 000 habitantes) es la histórica sede central de la fàbrica de carros FIAT. La ciudad ha experimentado últimamente un profundo proceso de transformación urbana empezado con la realización de los $X X$ Juegos Olímpicos Invernales del 2006 y antes de ellos, con el abandono de millones de metros cuadrados de fábricas. Por esto, Turín hoy es un interesante caso práctico para estudiar. El escrito se desarrolla sobre una lectura critica de la experiencia del Urban Center Metropolitano (UCM), la asociación nacida en el 2005 con el objectivo de acompañar las transformaciones y el proceso de renovación urbana y territorial. UCM es una interesante experiencia a nivel ya metodológico u operativo: desarrolla el trabajo con diferentes actores públicos y privados. UCM va a explorar las diferentes declinaciones del proyecto de arquitectura, a partir de su especifidad principal, o sea el "dibujo de la forma". Por eso, dentro del trabajo de UCM el proyecto puede alcanzar formas diferentes: por ejemplo, instrumento de conocimiento, de prefiguración o de debate.

\section{PALABRAS CLAVE}

Proyecto de arquitectura, Forma de la ciudad, Transformación urbana
Este artículo es resultado de la Investigación "Pensare metropolitano / Metropolitan Thinking" desarrollada por la arquitecta Camorali en 201 I con el apoyo institucional de: Giovanni Goria Foundation, Politecnico de Torino, y Urban Center Metropolitano Torino, Italia.

** Arquitecta Ph D en Architecture and Building Design. Desde 2009 es profesora asociada en el área de Diseño Arquitectónico y Urbano en el Politecnico de Torino, Italia. Desde el 2005 hace parte del grupo Design Team at Urban Center Metropolitano Torino en Italia, una asociación que trabaja con actores públicos y privados en temas de transformación urbana y arquitectónica.

francesca.camorali@polito.it

francesca.camorali@urbancenter.to.it 


\section{INTRODUCTION}

Located in the North-West of Italy, Torino (900.000 inhabitants, I,6 million referring to its metropolitan area) is the historical city of the automotive company FIAT. The city has recently experienced a deep process of urban transformation, which began with the $X X$ Winter Olympic Games in 2006'. Before that, during the Eighties, it started with the disposal of millions of square meters of unused factories related to the crisis of the Italian industrial production ${ }^{2}$. For all these reasons, Torino is today an interesting case study to look at.

The paper particularly deals with a critical reading of the experience of the Urban Center Metropolitano Torino (UCM), an association that was born in 2005 for accompanying the urban and metropolitan planning and the city's renewal processes ${ }^{3}$.

World wide urban centers are associations and institutions whose main aim is to promote a broad debate on urban processes of transformation ${ }^{4}$. In the Italian context, urban centers are mostly public institution, related to the public government of the Italian cities: their main purpose is to communicate what is happening in town in term of architectural and urban modification. On the contrary, the Anglo-Saxon urban centers focus not only on communication activities, but they also work on urban design, creating scenarios of transformation for the cities.

Among these different types and aims, the UCM of Torino is different from the other Italian urban centers, because of its activity focused both on communication and urban design that makes it more similar to the Anglo-Saxon model. Particularly looking at its urban design activities, UCM is an interesting experience from both a methodological and an operational point of view: doing its work with the various actors, the public and the private ones, UCM explores different uses of the architectural project, practicing its main skill that is to "draw a shape".

We may say that in the UCM's activities the project can acquire many different roles.

First of all, the project can be a tool of knowledge. It could seems banal, but the reductionist role played by the land use instruments - for example the "Piano Regolatore" (General Plan) - has critical effects on the outcomes of urban changing processes. The nature of these tools is ontologically un-morphological: they are not able to read and interpret a certain context as an "active support", as a rich stratification of material and immaterial deposits ${ }^{5}$. On the contrary, the project could become a useful device to increase that knowledge, passing through a morphological way of seeing: a morphological look that is synthetic but that it's also able to draw alternative "shapes" for the future of a city or a territory.

From this theme we can derive the second focus of this paper: the project as a tool of foreshadowing, that means the possibility for the project and for its main instrument of expression - the drawing of a certain shape - to be interpreted today as a way to imagine

I Among the wide panorama of publications on these themes, see in particular: FASSINO,Giulietta. SPINELLI, Carlo. (Edited by). Contemporary Turin. Guide to architectures. Barcelona-Trento: LISt/Actar. 20II.

2 Referring to the case study of Torino see: BAGNASCO, Arnaldo. La città dopo Ford. II caso di Torino. Torino: Bollati Boringhieri. 1990.

3 BAGNASCO, Arnaldo. OLMO, Carlo. (Edited by). Torino 0I I. Biografia di una città. Milano: Electa. 2008. The book collects the scientific contributions elaborated for the exhibition "TOII. Biografia di una città" (TOII. Biography of a city), edited by Urban Center Metropolitano (Torino, Officine Grandi Riparazioni. 2008).

4 MONARDO, Bruno. Urban Center. Una casa di vetro per le politiche urbane. Roma: Officina Edizioni. 2007.

5 DEMATTEIS, Giuseppe. "Per progettare il territorio". In: Archivio di studi urbani e regionali. Milano: Franco Angeli. No. 42. 1991 . 
and figure out different scenarios. This is a central aspect of the design disciplines: they should no longer be interpreted as mere authorial exercises, tied to a single personality of an "artist-architect"; otherwise they have to become specific know-how, inserted into peculiar moments and places.

Finally, the project could be a powerful tool of discussion: a tool that is open and unfixed, but that is also able to put in shapes different issues in order to define modification's rules of a place, to organize themes and choices and to interpret changes.

\section{URBAN CENTER METROPOLITANO TORINO}

The UCM was founded in 2005 by an agreement signed between the Government of Torino, Torino Internazionale - the association that coordinated the two Strategic Plans of the city between 2000 and $2006^{6}$ - and the Compagnia of San Paolo, one of the major banking foundation in Torino ${ }^{7}$. The "UCM Project" was conceived as an activity of the Second Strategic Plan of the city, when the debate over the quality of living is increasing more and more, not only among architects but also on the pages of the local newspapers. The deep process of urban transformation, that the city has experienced since the industrial disposal of the Eighties, began to be visible to the eyes of citizens with results and reactions that were often contradictory ${ }^{8}$. The UCM was born in this specific historical moment, defining its way of work as a possible answer to some fundamental questions. First of all, the idea that such a radical transformation of the city - as it is the one that interested Torino since Nineties - has to be accompanied by a public debate about the future of the city itself. Secondly, the idea that the public and private players could work together using the instrument of the architectural and urban design.

These are the main nodes around which this paper will focus on. First of all, how does the UCM work? Differently from the other Italian urban centers that work as a direct expression of a certain public government - for example the cases of Milano and Bologna (Italy) -, the UCM is an independent structure. This is a statement that carries out with it an important corollary: the UCM's accompanying activities on urban transformation project must not act on a "regulative" level (that is, a certain proposal has to be accepted because it will respect some certain rules); instead, its activities focus on an "argumentative" level of the debate (that means: a certain project has to be accepted because it will respond to both public and private interests increasing urban quality). Moving from this corollary we can keep together both the strength and the weakness of UCM.

If UCM is an independent association, its legitimacy to participate to the debate of urban transformation is not guaranteed once and for all. It has to be every time recognized by other players, both the public and the private ones: this is, of course, one of its greatest weaknesses. Otherwise, as an independent association, UCM can elaborate alternative scenarios based on a morphological level that deal the quality of urban environment. A way of work that could be a "disturbing element" among the administrative procedures and

6 In order to deal to the vocational crisis that interested Torino since the Eighties - with the closure of many industrial sites within the city - the local Government decided to elaborate a Strategic Plan for the future of the city. The first Strategic Plan was published in 2000 and the second one in 2006. See: Associazione Torino Internazionale. (Edited by). II Piano Strategico della città. Torino, 2000. Associazione Torino Internazionale. (Edited by). Secondo Piano Strategico dell'area metropolitana di Torino. Direzione e Obiettivi. Torino. 2006. See also the web-site: www.torino-internazionale.org.

7 The main Italian Banks have their own foundations, whose aim is to support initative and activities oriented to the development of a specific local context. Torino has two main banking foundation that are: Compagnia di San Paolo (Intesa San Paolo Bank) and Fondazione CRT (Cassa di Risparmio di Torino Bank).

8 See the articles published in: "Vicende e dibattiti torinesi". In: Atti e Rassegna Tecnica della Società degli Ingegneri e degli Architetti in Torino. No. I (September 2007). “Torino. Tredici anni di attuazione del PRG”. In: Atti e Rassegna Tecnica della Società degli Ingegneri e degli Architetti in Torino. Torino. No. I-2 (March-April 2008). 
processes, that breaks the linearity between the discussion and the approval of a certain project, doing it not in the name of a superior rationality but rather from the perspective of changing the way of looking to architectural and urban design: not only simple "procedures", but complex "processes" to chew on.

\section{THE CASE-STUDY OF TORINO. IF THE CONDITIONS ARE CHANGING}

Figure I. Former FIAT factory. Photo by $M$ D'Ottavio

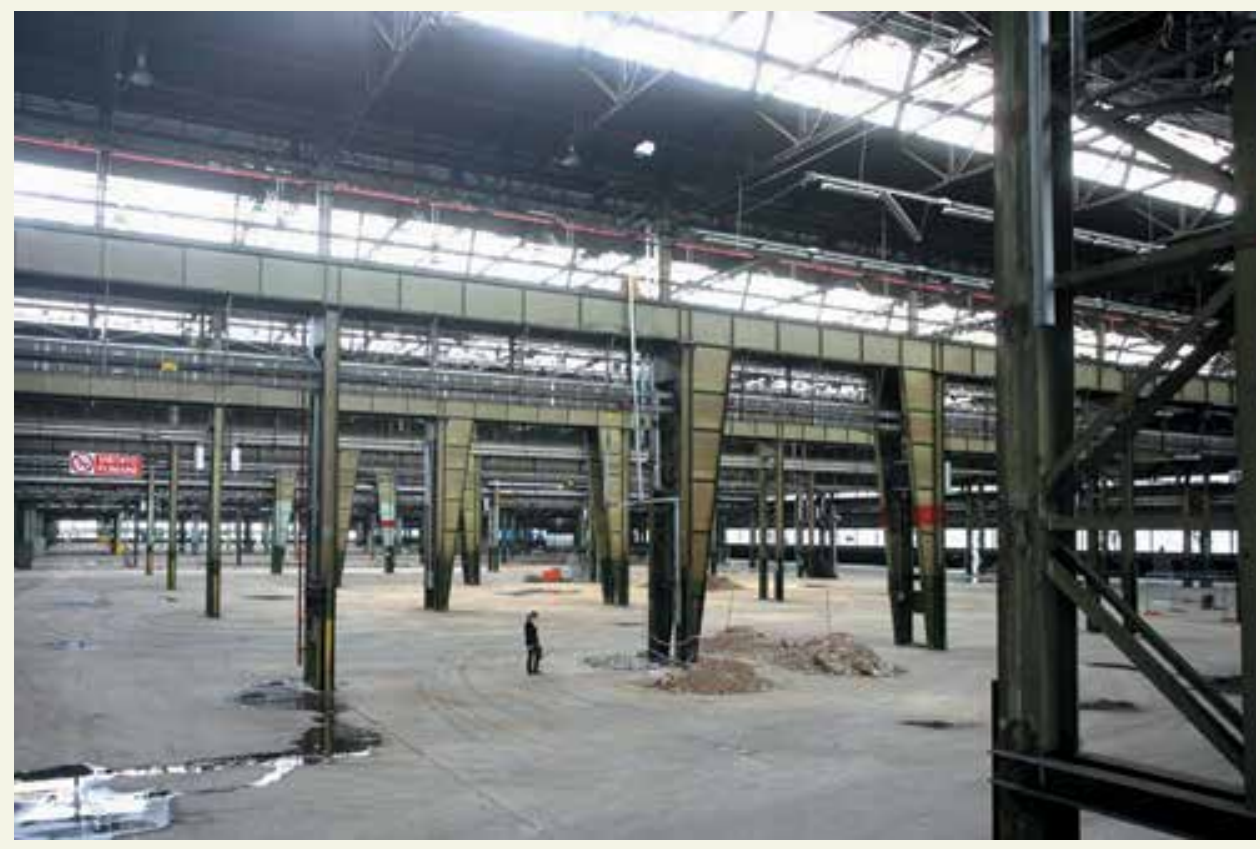

Figure 2. The first FIAT factory of Lingotto designed by Giacomo Mattè Trucco (1922). In 1982, after the industrial crisis, the factory was turned into a conference and shopping center. Architectural project: RPBW - Renzo Piano Building Workshop. Photo by M. D'Ottavio

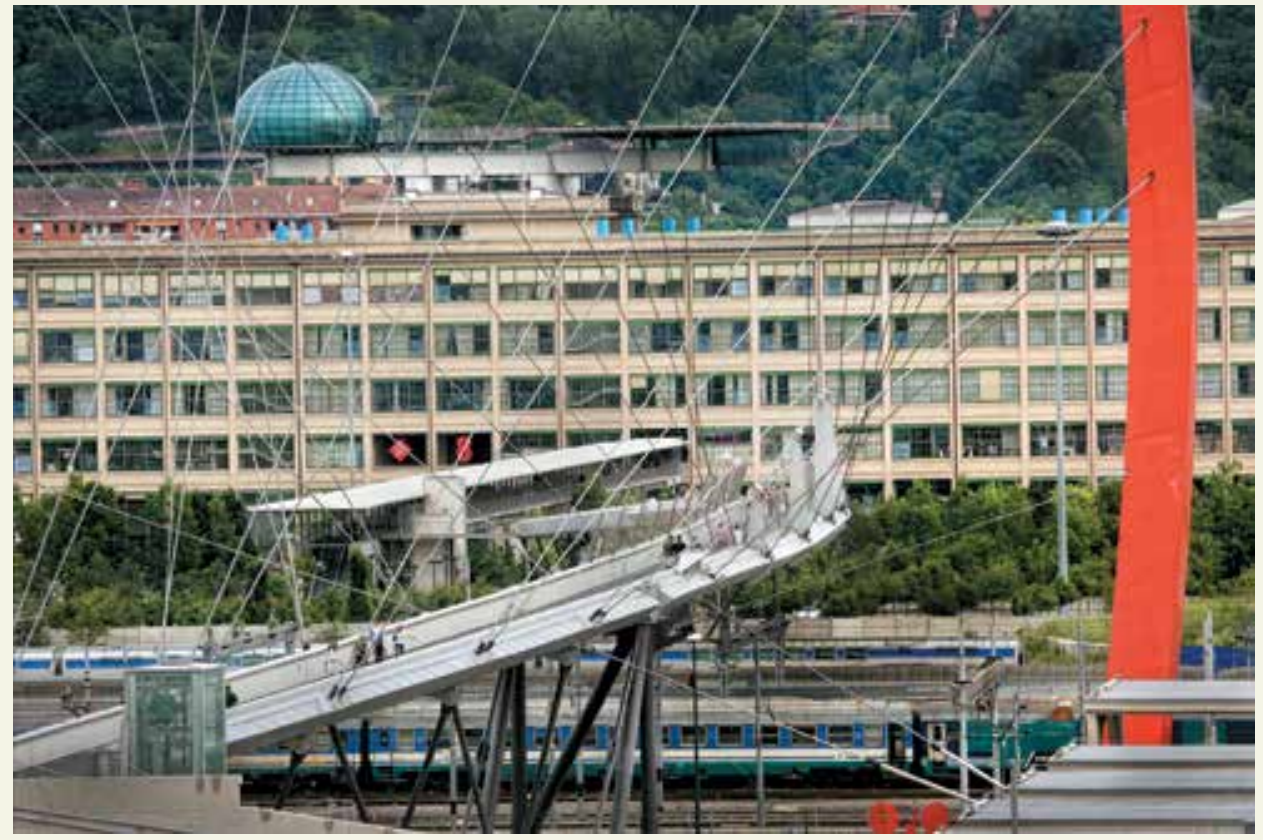



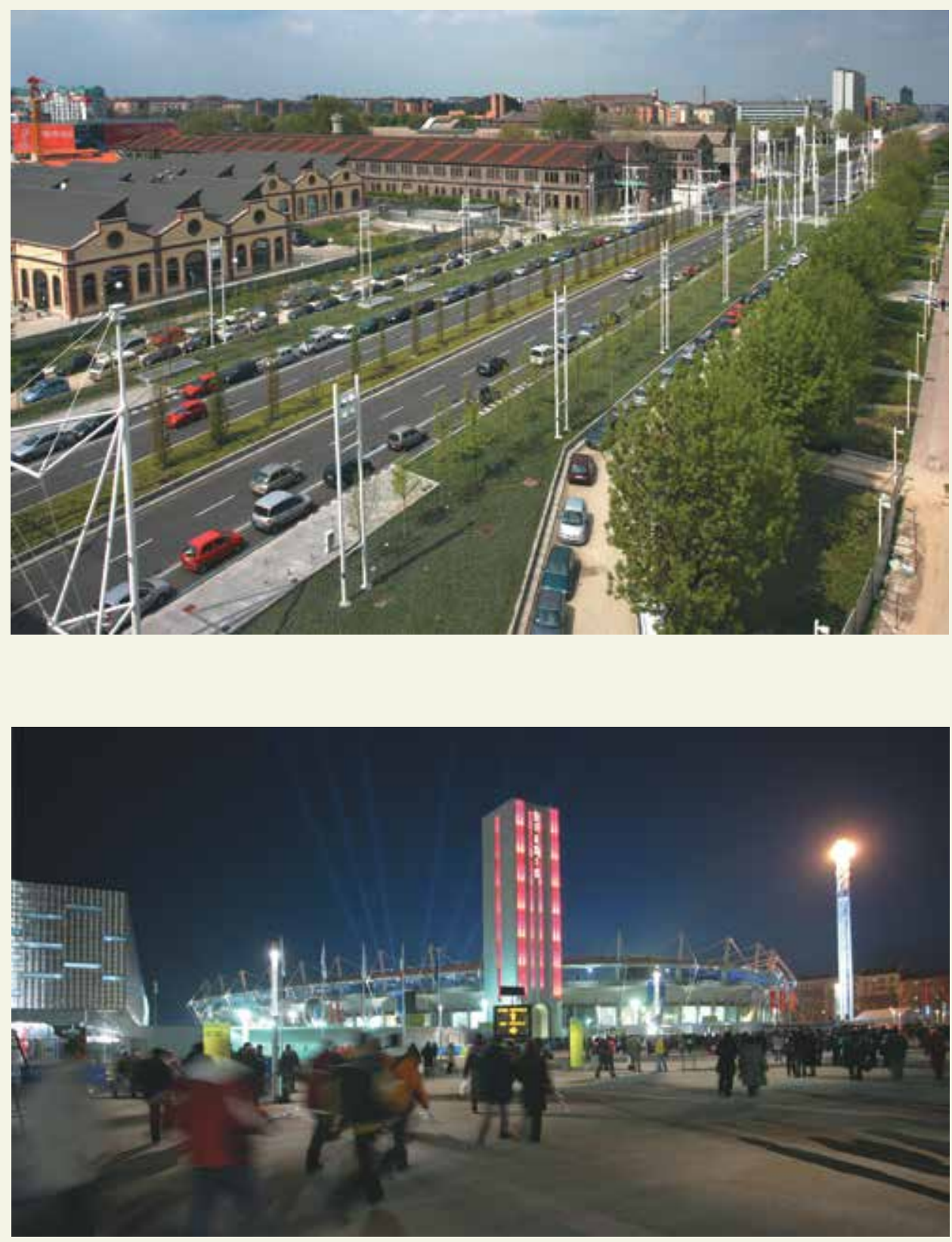

Torino, like many other Italian and European cities, is today facing a brand new season of its life. The consequences of the worldwide economic crisis, that hits the Western world during the last five years, can be found in different aspects of our life, even within the local context. The successful period - which is started in Torino in the Nineties with the transformations of the disposed industrial areas and that has found in the XX Winter Olympic Games (2006) an extraordinary moment of acceleration - has come today to its end. This was a strange period, we may say it was "addicted" of occasions and opportunities?. During
Figure 3. The "Central Backbone": the new inner boulevard built after the lowering of the railway tracks. It is one of the main urban transformation that started with the approval of the General Plan in 1995. Photo by M. D'Ottavio
Figure 4. Torino. The Olympic Stadium, renewed for the XX Winter Olympic Games of 2006 Photo by M. D'Ottavio

9 In order to better understand the role of the XX Winter Olympic Games in Torino's urban changes see: EAU VIVE. COMITATO G. ROTA. (Edited by). L'immagine del cambiamento. Sesto rapporto annuale su Torino. Torino: Edizioni Guerini e Associati. 2005. See also: EAU VIVE. COMITATO G. ROTA. (Edited by). Giochi aperti. Settimo rapporto annuale su Torino. Torino: Edizioni Guerini e Associati. 2006. 
the last thirty years, many other European cities - such as Bilbao, Lyon and Barcelona ${ }^{10}$ have governed a deep process of rereading and reinterpretation of their vocation and direction of development. For us, as researchers, the rebirth of these cities means that they become privileged places to look at: they becomes laboratories. We may say that the "city" itself returned to be an interesting dimension to be read, also from the point of view of the architectural and urban studies' literature.

In the city of Torino this change has passed through the elaboration of a new General Plan, that was approved in 1995, and two Strategic Plans, the first one in 2000 and the second one in 2006. The metamorphosis that these events have left to the city - both in its social, economic and physical components - was radical. But what was the features of this metamorphosis?

First of all, the rapidity of change: the crisis of industrial vocation obliged to a urgent research - that is primarily governed by the local political class - of a different target for the future. This is why during this period every opportunities of investment couldn't absolutely be lost. The city's slogan ("Always on the move"), through which Torino was presented to the World during the 2006 Olympic Games, is perhaps the most synthetic expression of the vision that has characterized this period of the city's life. Although the critical elements are not lacking, the process of change that has invested Torino since Nineties has some good aspects: first of all, the ability to inspire a wider debate about the image and the future of the city, which involved the local community in its different forms and expressions - from the citizens to the political and the intellectual classes. This is the most interesting aspect: the growth of a public debate about the possibilities for Torino to become something different. Not only more the "city of FIAT" but a city that, even starting by its specific industrial culture, could be able to become a competitive reality in the European and International context.

It is moving from this substrate, built on the experiences of the last thirty years, that Torino is now facing a new season of its life: the reverberations that the global economic crisis may have on the local dimension could be an opportunity to exit from the rhetoric of the "city always on the move", starting again to reflect critically on new key-themes through which formulate policies for the next future. If the conditions are deeply changing, the city must necessarily reflect on a process of revision and redefinition of its image. The issue is not, as it was in the Nineties, an antidote to the deep changes brought by the industrial crisis. Today, the goal for Torino must be the selection of priorities and choices through which interpret and direct the change of the city within a framework of European and International competition.

\section{BETWEEN IMAGES AND PLAYERS}

The pursuit of these goals means also and above all to redefine the relationship between public and private players and to rethink some kind of images for the city's change.

Looking at the relationship between images and players, Torino is an interesting casestudy. Its urban history is strictly connected to some shared "ideas of the city", around which it was possible to condense debates and reflections on the options of change. In particular, inside the experience of Torino, the physical transformation of the city are

10 The example of Bilbao (Spain) is interesting for the important role played by an "extraordinary" architecture: the new Guggenheim Museum, designed by Frank $O$. Gehry and opened in 1997, became the worldwide symbol of the city's rebirth. Few years earlier, Barcelona (Spain) deeply rethinked and renewed the city's vocation starting from the opportunity of the XXV Olympic Games (1992) 


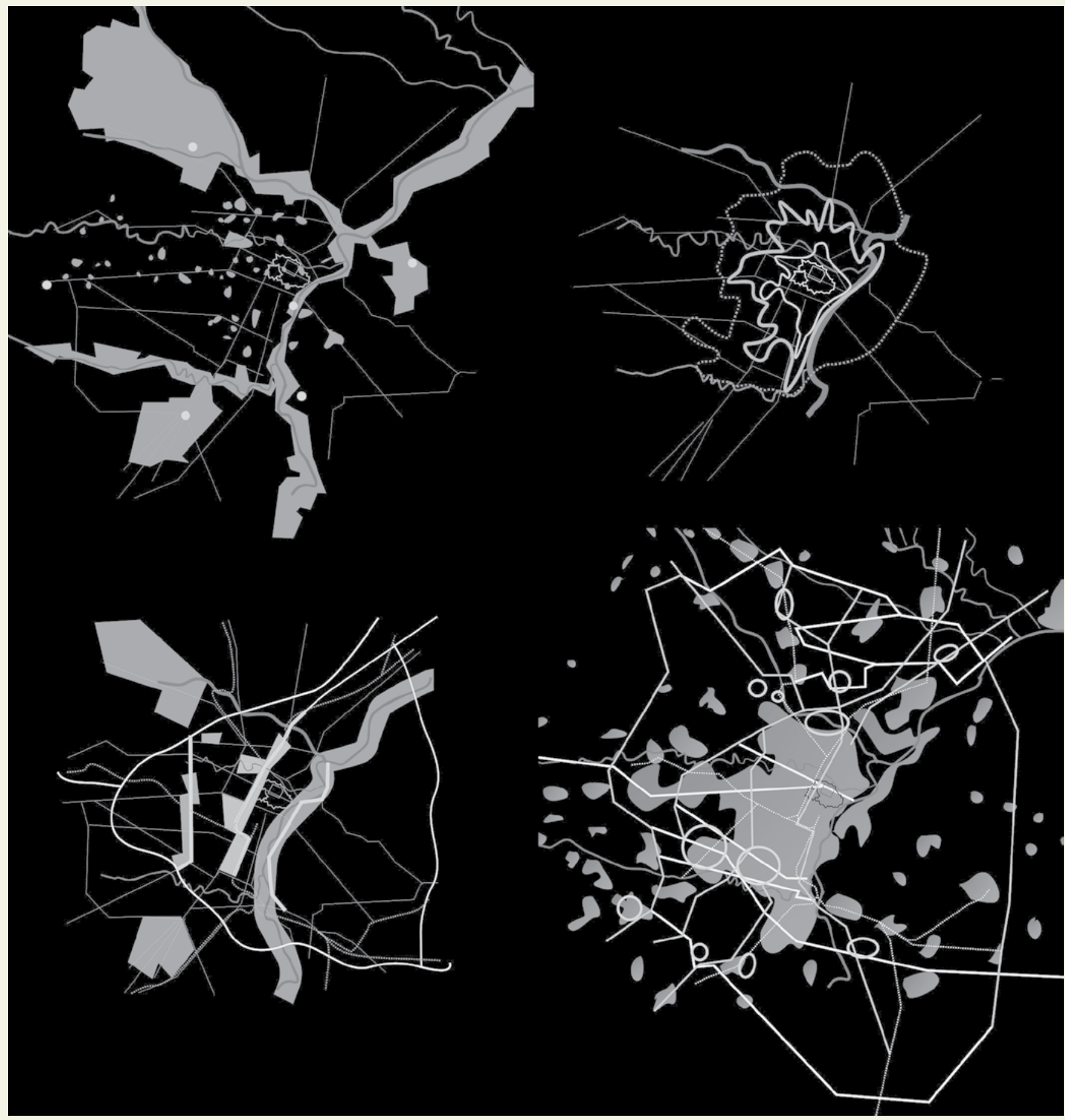

strictly connected to the social and economic local players" ${ }^{\prime \prime}$. This is the reason why today, in order to describe the city and its recent changes, it's necessary to pass through a physical representation of the future - the image of the tomorrow's city - that plays a key role in guiding projects and processes of change.

The issue of sharing images on the future of the city must not be misunderstood: it doesn't
Figure 5. Different images of the city of Torino. Starting from left and high: the Baroque system of the royal residences all around the city center; the image of the "Big Hand" by Giorgio Rigotti (1955); the image of the General Plan (1995); the image of the "City of cities" elaborated by the Strategic Plan (2000)

II DE ROSSI, Antonio. DURBIANO, Giovanni. Torino 1980-20II. La trasformazione e le sue immagini. Torino: Allemandi. 2006. See also: BELLIGNI, Silvano. RAVAZZA, Stefania. La politica e la città. Regime urbano e classe dirigente a Torino. Bologna: II Mulino. 2012 
Figure 6. Torino. "Spina 3" district: one of the main urban transformation promoted by the General Plan of the city. Photo by M. D'Ottavio
Figure 7. The Baroque city center. Pphoto by M. D'Ottavio
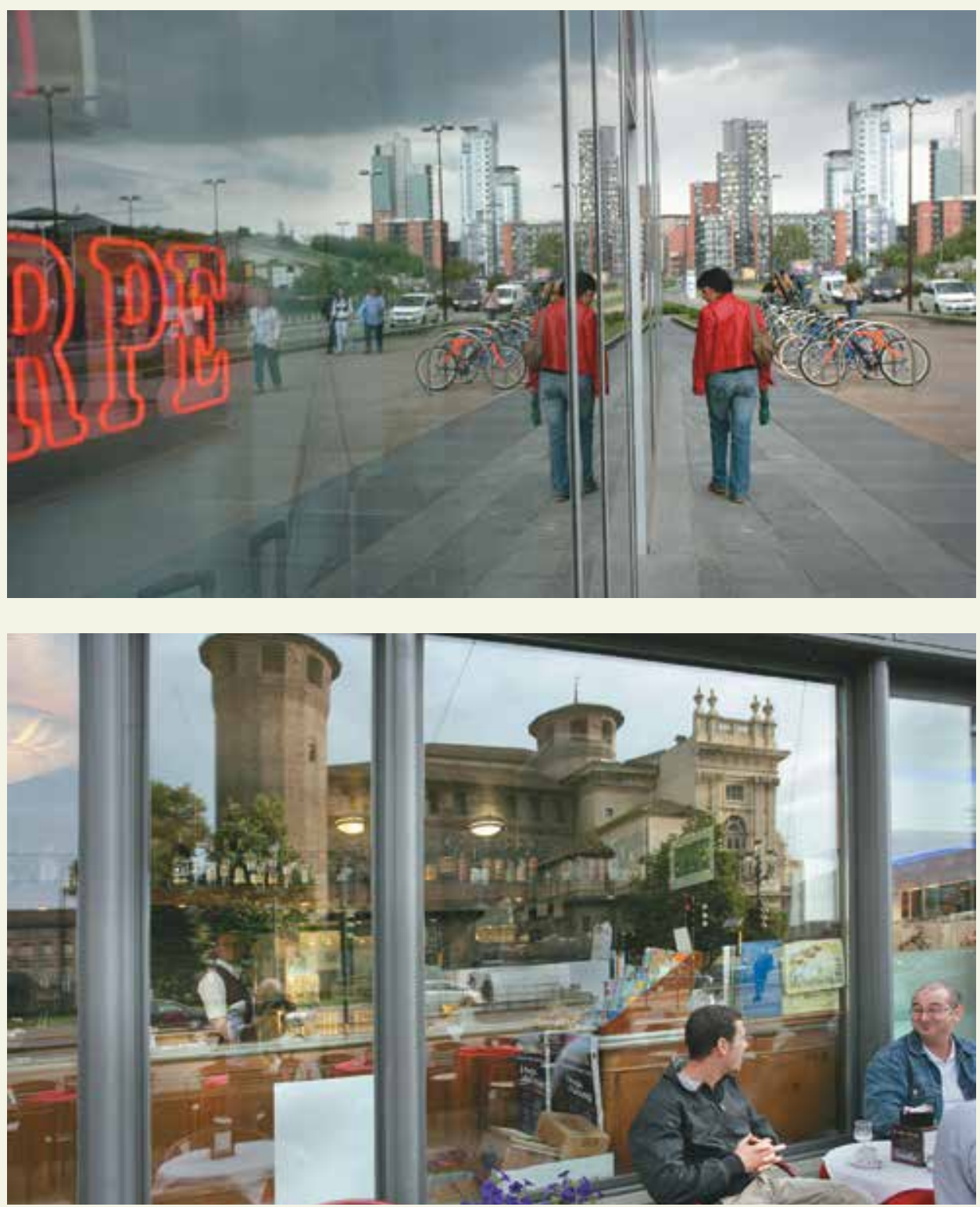

deal with some kind of "new tools" to facilitate the convergence between different decision makers. Otherwise the perspective of research I want to discuss here is the one that sees the architectural project as a useful tool of knowledge: it is inside the urban arena, where the relationship between images and players are more complex, that the designing disciplines could become interpretative tools. From this point of view, the Urban Center Metropolitano of Torino is an interesting experience to look at.

\section{SOME THOUGHTS STARTING FROM PRACTICES}

The design of the physical shape of a certain urban change could potentially be a useful tool among the practices of a city's government: the activities of UCM focus daily on this kind of work. It seems interesting now to develop some thoughts moving from these practices ${ }^{12}$.

12 DE ROSSI, Antonio. ANTONELLI, Paolo. ARMANDO Alessandro. CAMORALI, Francesca. Dimensione dialogica e dimensione morfologica. L'esperienza dell'Urban Center Metropolitano di Torino. In: Evangelisti, Francesco. Orlando, Piero. Piccinini, Mario. (Edited by). Disegnare la città. Urbanistica e architettura in Italia nel Novecento: appunti da un ciclo di conferenze. Ferrara: SATE Industria Grafica. 201 I. 
First of all: the importance of using the architectural and urban design in its open and argumentative meaning. The use of drawing as a device for discussion, which constantly enters into the ordinary processes of transformation of the city, risks to be misunderstood especially by points of view that are external to the design disciplines. It could happen that a project, made to represent a possible idea of urban transformation, is interpreted as something fixed and no longer editable. On the contrary, UCM tries to explore the opportunities related to a "weaker idea" of the architectural project ${ }^{13}$, opening new work's perspectives. Let's accept that some project conditions are already etched into a given context in terms of forms, of geographies and of the symbolic languages of built landscapes. Let's come to terms with them, examining them critically, reinterpreting them not as constraints, but as opportunities with which to work, and as semantic reserves that help in making choices that would otherwise be boundless and always legitimate. Let's acknowledge the continuity of architecture within architectures, appealing constantly to the tangible conditions our work. Let's recognize a work as having a nature that is apart from itself, external to its genesis in a laboratory or as part of a cycle (of decision, economics, culture or construction) in which a work confirms the very possibility of its architecture.

A second aspect of the UCM's activities is the endless need for his own projects to be "activated" by the players sitting at the decisional tables, in order to get them out from a simple visible image and become real tools for discussion. In this case the risk is to confuse the development of urban policies and practices with their own rhetoric. This is another interesting aspect that emerges from the UCM's experience, that is the ability of the architectural project to become a "boundary object" between different disciplines, interests and languages.
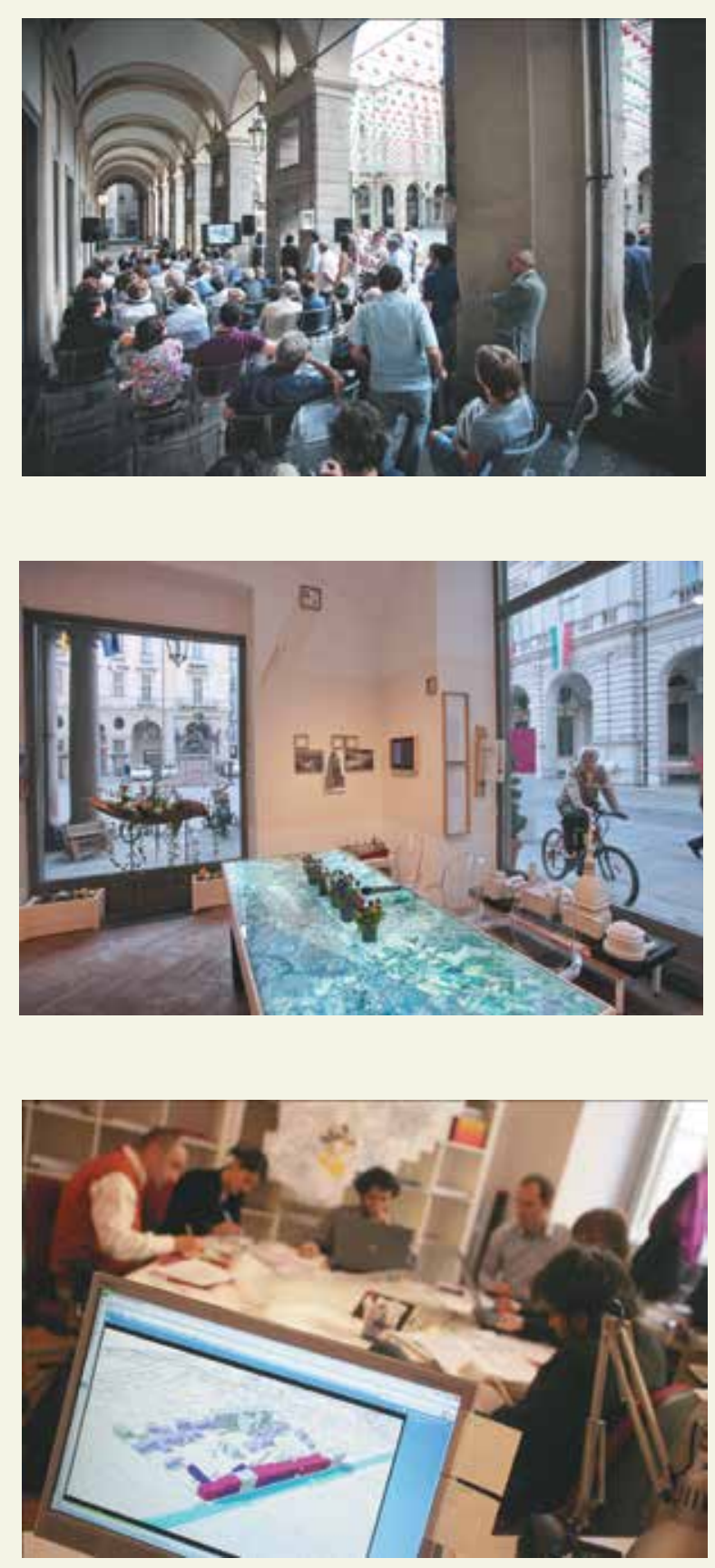

Figure 8. Inauguration of the public space of Urban Center Metropolitano in the historical center of Torino, 2012. Photo by M. D'Ottavio

Figure 9. The public space of Urban Center Metropolitano. Photo by M. D'Ottavio
Figure 10. Designing activity at the Urban Center Metropolitano. Photo by M. D'Ottavio

13 Referring to the idea of a weaker architectural design see the philosophical concept of "weak project" introduced during the Eighties by: VATTIMO, Gianni. ROVATTI, Pier Aldo. (Edited by). II pensiero debole. Milano: Feltrinelli. 1983. 
"Boundary objects are objects which are both plastic enough to adapt to local needs and the constraints of the several parties employing them, yet robust enough to maintain a common identity across sites. [...] They have different meanings in different social worlds but their structure is common enough to more than one world to make them recognizable, a means of translation ${ }^{14}$ ". The concept of "boundary object" was developed by Star and Griesemer in 1988 to explain the positive results of interaction between conflicting groups with divergent objectives. Their hypothesis is that - in order to carry out projects within complex contexts - is necessary that they intercept different strategies without trying to make them converge. That's why the architectural project as a boundary object could usefully express a representation of the different arguments that pertains to the physical form of city's changes ${ }^{15}$.

Starting from this point of view, the opportunities that can be seen from the UCM's experience deals more with the inertia of the drawings rather than with the value of shared images of the future. In this sense, the architectural project could be considered not as a framework to work towards a progressive understanding of the parts, but rather as a form of writing that leaves traces, strengthening them by subsequent agreements. Inertia is a property of the complex drawings on a territory or a city, in which the signs refer to rationality that are first separated and then superimposed, modified or reassembled. Having no immediate relation to the processes of executive action, these architectural designs are hybrid and continuously uncertain ${ }^{16}$ : they are figural images that can be easily absorbed by media circuits. On the other hand, they can contribute to map both the political and the technical priorities of a certain urban government.

This uncertain condition may also be, potentially, the positive margin within which all the drawings could become the main frame of a process, converting the inertial factors in the design of shared decisions. That is, I could say, the metaphor of a "construction site": that is collective, open and constantly changing, but that is also oriented to concretely build something.

\section{BIBLIOGRAPHY}

Associazione Torino Internazionale. (Edited by). II Piano Strategico della città. Torino, 2000.

Associazione Torino Internazionale. (Edited by). Secondo Piano Strategico dell'area metropolitana di Torino. Direzione e Obiettivi. Torino. 2006.

BAGNASCO, Arnaldo. La città dopo Ford. Il caso di Torino. Torino: Bollati Boringhieri. 1990.

BAGNASCO, Arnaldo. OLMO, Carlo. (Edited by). Torino 0II. Biografia di una città. Milano: Electa. 2008.

14 STAR, Susan Leigh. Griesemer, James R.. "Institutional ecology, 'translations' and boundary objects: amateurs and professionals in Berkeley's Museum of vertebrate zoology, 1907-39". In: Social Studies of Science No. 19, 1989; p.393.

15 Referring to this interpretation of the "boundary object" applied to the Italian context see: BALDUCCI, Alessandro. "Trading Zone" un concetto utile per alcuni dilemmi della pianificazione. In: TODROS, Anna. VITALE BROVARONE, Elisabetta. (Edited by). Abitare l'Italia. Territori, economie, disuguaglianze. Torino: Politecnico di Torino. 201 I.

16 On these themes see the contribution elaborated during the Sixties by the Italian architect and critic Vittorio Gregotti: GREGOTTI, Vittorio. II territorio dell'architettura. Milano: Feltrinelli. 1966. 
BALDUCCI, Alessandro. "Trading Zone" un concetto utile per alcuni dilemmi della pianificazione. In: TODROS, Anna. VITALE BROVARONE, Elisabetta. (Edited by). Abitare l'Italia. Territori, economie, disuguaglianze. Torino: Politecnico di Torino. $201 \mathrm{I}$.

DE ROSSI, Antonio. ANTONELLI, Paolo. ARMANDO Alessandro. CAMORALI, Francesca. Dimensione dialogica e dimensione morfologica. L'esperienza dell'Urban Center Metropolitano di Torino. In: Evangelisti, Francesco. Orlando, Piero. Piccinini, Mario. (Edited by). Disegnare la città. Urbanistica e architettura in Italia nel Novecento: appunti da un ciclo di conferenze. Ferrara: SATE Industria Grafica. 20I I.

DE ROSSI, Antonio. DURBIANO, Giovanni. Torino 1980-20II. La trasformazione e le sue immagini. Torino: Allemandi. 2006. See also: BELLIGNI, Silvano. RAVAZZA, Stefania. La politica e la città. Regime urbano e classe dirigente a Torino. Bologna: II Mulino. 2012.

DEMATTEIS, Giuseppe. "Per progettare il territorio". In: Archivio di studi urbani e regionali. Milano: Franco Angeli. No. 42. 1991.

EAU VIVE. COMITATO G. ROTA. (Edited by). Giochi aperti. Settimo rapporto annuale su Torino. Torino: Edizioni Guerini e Associati. 2006.

EAU VIVE. COMITATO G. ROTA. (Edited by). L'immagine del cambiamento. Sesto rapporto annuale su Torino. Torino: Edizioni Guerini e Associati. 2005.

FASSINO, Giulietta. SPINELLI, Carlo. (Edited by). Contemporary Turin. Guide to architectures. Barcelona-Trento: LISt/Actar. 20I I

GREGOTTI, Vittorio. Il territorio dell'architettura. Milano: Feltrinelli. 1966.

MONARDO, Bruno. Urban Center. Una casa di vetro per le politiche urbane. Roma: Officina Edizioni. 2007.

STAR, Susan Leigh. Griesemer, James R.. "Institutional ecology, 'translations' and boundary objects: amateurs and professionals in Berkeley's Museum of vertebrate zoology, 1907-39". In: Social Studies of Science No. 19, 1989; p.393.

VATTIMO, Gianni. ROVATTI, Pier Aldo. (Edited by). II pensiero debole. Milano: Feltrinelli. 1983. www.torino-internazionale.org. 